Огляди літератури, оригінальні дослідження, погляд на проблему, випадок з практики, короткі повідомлення УДК 612.015.1-02:616.137/.147-905.4/-007.271-06:616.147-005.1]-092.9

DOI 10.11603/1811-2471.2020.v.i2.11320

\title{
ВПЛИВ ГОСТРОЇ КРОВОВТРАТИ, УСКЛАДНЕНОЇ ІШЕМІЄЮ-РЕПЕРФУЗІЄЮ КІНЦІВКИ, НА АНТИОКСИДАНТНО-ПРООКСИДАНТНИЙ БАЛАНС ПЕЧІНКИ ТА ЙОГО КОРЕКЦІЯ КАРБАЦЕТАМОМ
}

\author{
Тернопільський національний медичний університет імені І. Я. Горбачевського МОЗ України
}

РЕЗЮМЕ. Мета - з'ясувати вплив гострої крововтрати, ускладненої ішемією-реперфузією кінцівки, на антиоксидантно-прооксидантний баланс печінки та ефективність корекції виявлених порушень карбацетамом.

Матеріал і методи. Експерименти виконано на 108 нелінійних щурах-самцях масою 200-220 г. Усіх тварин поділили на п'ять груп: контрольну та чотири дослідних. Усі втручання виконані під тіопентало-натрієвим наркозом. У першій дослідній групі тваринам моделювали ішемію-реперфузію кінцівки шляхом накладання проксимально на ліву лапку смужки еластичного джгута «SWAT-T» (CША) шириною 10 мм на 120 хв. У другій дослідній групі моделювали гостру крововтрату (20 \% від о6'єму циркулюючої крові) шляхом пересікання стегнової вени. У третій дослідній групі ці ушкодження поєднували. У четвертій дослідній групі тваринам з гострою крововтратою та ішемією-реперфузією кінцівки внутрішньоочеревинно вводили карбацетам в дозі 5 мг на кілограм маси тварини. В контрольній групі тварин вводили в наркоз, застосовуючи еквівалентну дозу тіопенталу натрію, накладали джгут на 2 год без припинення кровотоку і в подальшому брали для досліджень через 1 год.

Через 1 і 2 години, а також через 1, 7 і 14 діб в умовах тіопенталонатрієвого наркозу тварин дослідних груп виводили з експерименту методом тотального кровопускання з серця. В гомогенаті печінки визначали вміст реагентів до тіобарбітурової кислоти й активність каталази. На основі цих даних розраховували антиоксидантно-прооксидантний індекс (АПІ).

Результати. Внаслідок моделювання лише ішемії-реперфузії кінцівки в печінці зростала величина АПІ з максимумом через 7 діб спостереження, що зумовлено як підвищенням вмісту реагентів до тіобарбітурової кислоти, так і збільшенням активності каталази. До 14 доби величина АПІ знижувалася, проте не досягала рівня контролю. Під впливом гострої крововтрати величина АПІ у печінці різко зменшувалася, що викликано зростанням вмісту ТБК-активних продуктів ПОЛ на тлі зниження активності каталази. Додаткова двогодинна ішемія кінцівки з наступною реперфузією на тлі гострої крововтрати зумовлювала ще більше зниження величини АПІ в печінці, що виявилося статистично вірогідним, порівняно з іншими дослідними групами у всі терміни спостереження. Застосування карбацетаму у групі тварин з гострою крововтратою, ускладненою ішемією-реперфузією кінцівки, порівняно з тваринами без корекції, викликало істотне зростання величини АПІ через 7-14 діб експерименту, що свідчить про його антиоксидантний вплив.

Висновки. Внаслідок двогодинної ішемії та реперфузії кінцівки в печінці суттєво зростає величина АПІ з максимумом через 7 діб реперфузійного періоду, яка до 14 доби не досягає рівня контрольної групи. За умов гострої крововтрати величина АПІ в печінці різко зменшується, досягає мінімуму через 1 добу й до 14 доби залишається істотно меншою, ніж у контролі. Додаткове моделювання ішемії-реперфузії кінцівки на тлі гострої крововтрати супроводжується найбільшим зниженням величини АПІ в печінці у всі терміни спостереження.

Застосування впродовж 7-14 діб реперфузійного періоду карбацетаму в тварин із гострою крововтратою, ускладненою ішемією-реперфузією кінцівки, порівняно з тваринами без корекції, викликає істотне зростання величини АПІ, що свідчить про ефективність препарату за умов модельованої патології.

КлючовІ словА: печінка; крововтрата; ішемія-реперфузія кінцівки; антиоксидантно-проксидантний баланс; карбацетам.

Вступ. Тероризм і локальні збройні конфлікти стали характерною ознакою сьогодення. За даними статистики, у 80-90 \% випадків смертей унаслідок застосування вогнепальної зброї та вибухових пристроїв відмічають ураження кінцівок 3 масивною крововтратою [10]. Золотим стандартом рятування життя таких поранених і постраждалих визнано застосування кровоспинних джгутів з повною зупинкою артеріального кровотоку не більше як на дві години [18].

Проте існує ряд досліджень, в яких встановлено, що повне знекровлення кінцівки навіть протягом двох годин може зумовити пошкодження нервів і судин під джгутом, міонекроз, рабдоміоліз, тромбоз глибоких вен $[7,11]$. Однак ще більші порушення як у м'яких тканинах кінцівки, так і на системному рівні, автори відмічали після ії реперфузії. Потрапляючи у системний кровотік, токсини з ішемізованої кінцівки можуть зумовити метаболічний ацидоз, гіперкаліємію та міоглобінемію [16], накопичення в гомогенатах м'язів, внутрішніх органів та плазмі крові супероксид-радикалу [13], зниження загального антиоксидантного захисту [12], збільшення утворення прозапальних цитокінів [20]. Усе це на тлі додаткових ушкоджень створює передумови для розвитку поліорганної недостатності $[8,19,21]$.

Застосування джгута при пораненнях кінцівок рідко є своєчасним, тому, як правило, поєдну- 
Огляди літератури, оригінальні дослідження, погляд на проблему, випадок з практики, короткі повідомлення ється з масивною крововтратою. Спільним патогенним механізмом ішемії-реперфузії і крововтрати є поглиблення процесів ліпідної пероксидації, зумовлене гіперпродукцією активних форм кисню (АФК) $[15,17]$, що посилюється внаслідок надходження токсинів з ішемізованої кінцівки.

На сьогодні системний вплив гострої крововтрати та ішемії-реперфузії кінцівки на стан ліпідної пероксидації та антиоксидантного захисту в печінці - центральному органі детоксикації, - вивчений недостатньо. Немає даних щодо ефективності за цих умов карбацетаму, який має антиоксидантну, імуномоделювальну, детоксикаційну, мембраностабілізуючу і тканинопротекторну дію [4].

Мета - з'ясувати вплив гострої крововтрати, ускладненої ішемією-реперфузією кінцівки, на антиоксидантно-прооксидантний баланс печінки та ефективність корекції виявлених порушень карбацетамом.

Усіх тварин поділили на п'ять груп: контрольну та чотири дослідних (по 6 щурів у групі). Усі втручання виконані під тіопенталонатрієвим наркозом. У першій дослідній групі тваринам моделювали ішемію-реперфузію кінцівки шляхом накладання проксимально на ліву лапку смужки еластичного джгута «SWAT-T» (США) шириною 10 мм на 120 хв. Джгут затягували відповідно до нанесеного на ньому індикатора ефективного тиску, який припиняє кровотік. У другій дослідній групі моделювали гостру крововтрату (20 \% від об'єму циркулюючої крові) шляхом пересікання стегнової вени. У третій дослідній групі ці ушкодження поєднували. У

четвертій дослідній групі тваринам із гострою крововтратою та ішемією-реперфузією кінцівки з корегувальною метою внутрішньоочеревинно вводили карбацетам (Інститут фізико-органічної хімії та вуглехімії НАН України, Донецьк) в дозі 5 мг на кілограм маси тварини [4]. В контрольній групі тварин вводили в наркоз, застосовуючи еквівалентну дозу тіопенталу натрію, накладали джгут на 2 год без припинення кровотоку і в подальшому брали для досліджень через 1 год.

Через 1 і 2 години, а також через 1, 7 і 14 діб в умовах тіопенталонатрієвого наркозу піддослідних тварин виводили з експерименту методом тотального кровопускання з серця. В гомогенаті печінки визначали вміст реагентів до тіобарбітурової кислоти (ТБК-активних продуктів ПОЛ) - одного із основних скринінгових показників активності процесів ліпідної пероксидації [3], і активність каталази - ключового компонента ферментативної ланки антиоксидантного захисту [6]. На основі цих даних розраховували антиоксидантно-прооксидантний індекс (АПІ = активність каталази / вміст ТБК-активних продуктів ПОЛ) [4].

Оцінку вірогідності відмінностей між експериментальними групами проводили з використанням непараметричного критерію Манна-Уїтні.

Результати й обговорення. В результаті проведених експериментів встановлено, що величина АПІ після моделювання ішемії-реперфузії кінцівки зростала (табл. 1, рис. 1) й в усі терміни статистично вірогідно перевищувала рівень контролю $(p<0,05)$.

Таблиця 1. Величина АПІ печінки (ум.од.) після гострої крововтрати, ускладненої ішемією-реперфузією кінцівки (Me (LQ; UQ)) - медіана (нижній і верхній квартилі)

\begin{tabular}{|c|c|c|c|c|c|}
\hline \multirow{2}{*}{ Дослідна група } & \multicolumn{5}{|c|}{ Термін реперфузійного періоду } \\
\hline & 2 год & 3 год & 1 доба & 7 доба & 14 доба \\
\hline \multicolumn{6}{|c|}{ Контроль $=25,14(22,11 ; 27,73)(n=6)$} \\
\hline $\begin{array}{l}\text { Дослідна група } 1 \\
\text { Ішемія-реперфузія }\end{array}$ & $\begin{array}{c}69,62^{*} \\
(66,04 ; \\
79,77) \\
(n=6)\end{array}$ & $\begin{array}{l}67,14^{*} \\
(61,12 ; \\
70,59) \\
(n=6)\end{array}$ & $\begin{array}{c}60,93^{*} \\
(55,37 \\
68,75) \\
(n=6)\end{array}$ & $\begin{array}{l}92,09^{*} \\
(82,04 \\
68,75) \\
(n=6)\end{array}$ & $\begin{array}{l}77,59^{*} \\
(70,58 \\
82,15) \\
(n=6)\end{array}$ \\
\hline $\begin{array}{l}\text { Дослідна група } 2 \\
\text { Крововтрата }\end{array}$ & $\begin{array}{c}13,08^{*} \\
(12,42 ; \\
13,46) \\
(n=6)\end{array}$ & $\begin{array}{l}7,83^{*} \\
(7,27 \\
8,30) \\
(n=6)\end{array}$ & $\begin{array}{l}4,53^{*} \\
(4,05 \\
4,91) \\
(n=6)\end{array}$ & $\begin{array}{l}7,04^{*} \\
(6,78 \\
7,86) \\
(n=6)\end{array}$ & $\begin{array}{l}11,21^{*} \\
(10,65 \\
11,55) \\
(n=6)\end{array}$ \\
\hline $\begin{array}{l}\text { Дослідна група } 3 \\
\text { Ішемія-реперфузія+ } \\
\text { крововтрата }\end{array}$ & $\begin{array}{l}9,65^{*} \\
(9,31 \\
10,20) \\
(n=6)\end{array}$ & $\begin{array}{l}4,57^{*} \\
(4,51 ; \\
4,65) \\
(n=6)\end{array}$ & $\begin{array}{l}2,81^{*} \\
(2,74 \\
2,94) \\
(n=6)\end{array}$ & $\begin{array}{l}3,61^{*} \\
(3,42 \\
4,02) \\
(n=6)\end{array}$ & $\begin{array}{l}5,71^{*} \\
(5,14 \\
6,70) \\
(n=6)\end{array}$ \\
\hline$P_{1-2}$ & $<$ & $<$ & $<$ & $<$ & $<$ \\
\hline$P_{1-3}$ & $<$ & $<$ & $<$ & $<$ & $<$ \\
\hline$P_{2-3}$ & $<$ & $<$ & $<$ & $<$ & $<$ \\
\hline
\end{tabular}

Примітки: 1. * - відмінності стосовно контрольної групи статистично вірогідні (р<0,05);

2. р $_{1-2}$ - вірогідність відмінностей між дослідними групами 1 і 2;

3. р $1-3_{-3}$ - вірогідність відмінностей між дослідними групами 1 і 3;

4. $\mathrm{p}_{2-3}$ - вірогідність відмінностей між дослідними групами 2 і 3. 
Огляди літератури, оригінальні дослідження, погляд на проблему, випадок з практики, короткі повідомлення

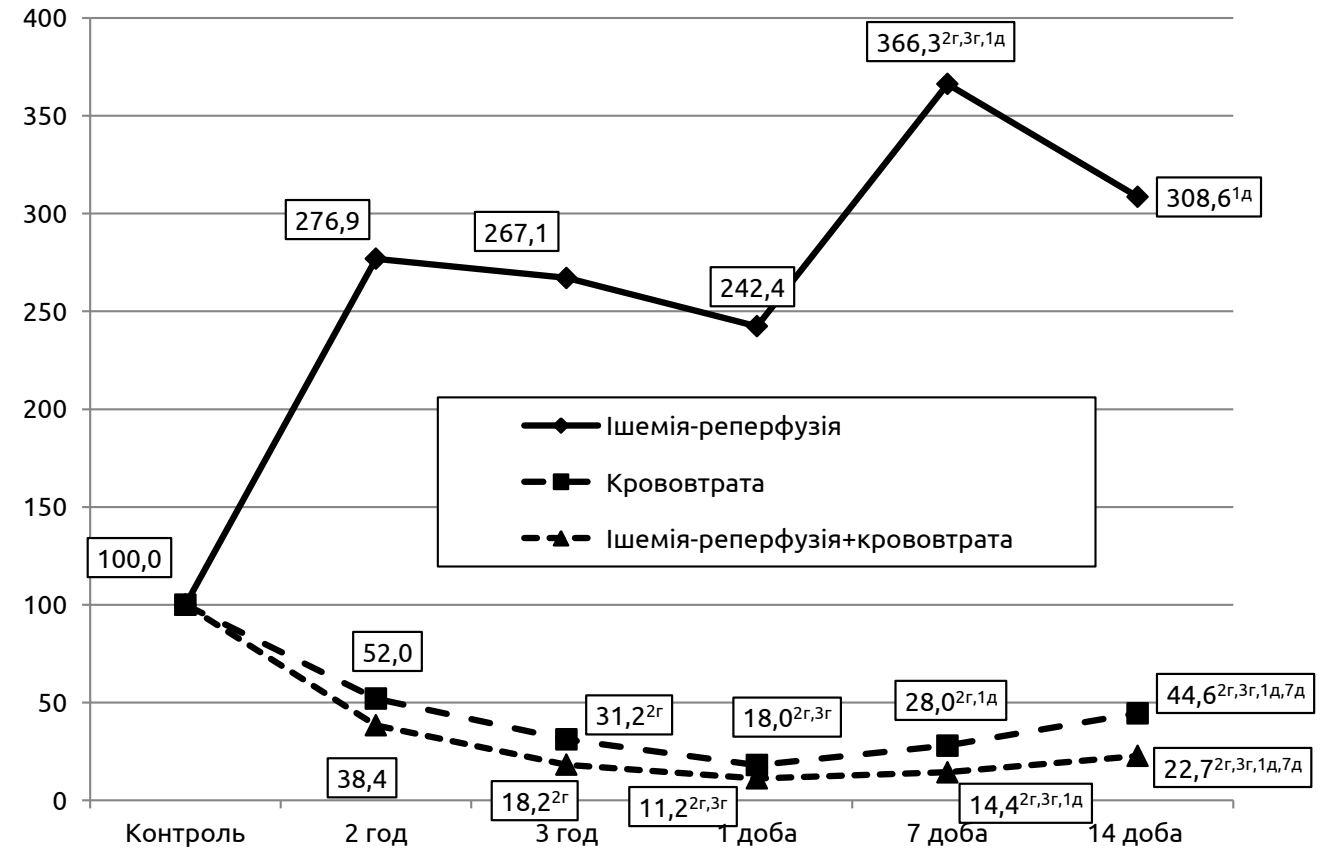

Рис. 1. Динаміка величини АПІ печінки (у відсотках до рівня контролю) після гострої крововтрати, ускладненої ішемією-реперфузією кінцівки.

(Примітка. 2г,3г,1д,7д - відмінності стосовно відповідно 2 і 3 год, а також 1 і 7 діб експерименту статистично вірогідні, p<0,05).

Показник досягав максимуму через 7 діб експерименту й був у 3,66 раза більшим, ніж у контролі $(p<0,05)$. В цей термін показник також перевищував усі попередні терміни спостереження $(p<0,05)$. До 14 доби показник знижувався, проте був у 3,09 раза більшим, ніж у контрольній групі $(p<0,05)$.

Після моделювання гострої крововтрати величина АПІ навпаки, знижувалася, й в усі терміни спостереження виявилася статистично вірогідно меншою, ніж у контролі $(p<0,05)$. Показник досягав мінімальної величини через 1 добу (на 82,0\% порівняно з контролем) й був істотно меншим порівняно з попередніми термінами спостереження $(p<0,05)$. До 14 доби величина АПІ в цій групі зростала, проте через 14 діб залишалася на 55,4 \% меншою, ніж у контролі $(p<0,05)$, хоча в цей термін статистично вірогідно перевищувала результати 3 год, 1 і 7 діб спостереження $(p<0,05)$.

За умов гострої крововтрати та ішемії-реперфузії кінцівки порушення величини АПІ печінки були найбільшими. Показник вже через 1 год експерименту порівняно з контролем знижувався на 61,6 \% і до 1 доби досягав 11,2 \% від рівня контролю $(p<0,05)$. В цей термін показник виявився істотно меншим, порівняно з іншими термінами спостереження $(p<0,05)$. До 14 доби величина АП। печінки зростала, ставала істотно більшою, порівняно з 3 год, 1 і 7 добами спостереження $(p<0,05)$, проте залишалася на 77,3 \% статистично вірогідно меншою, порівняно з контролем $(p<0,05)$.
Порівняння дослідних груп між собою показало, що після моделювання гострої крововтрати (дослідна група 2) величина АПІ у всі терміни спостереження була статистично вірогідно меншою, ніж після моделювання лише ішемії-реперфузії кінцівки (дослідна група 1) $\left(p_{1-2}<0,05\right)$. Після нанесення гострої крововтрати, ускладненої ішемієюреперфузією кінцівки (дослідна група 3), показник теж у всі терміни спостереження був істотно меншим, ніж у дослідній групі $1\left(p_{1-3}<0,05\right)$ та дослідній групі 2 ( $\left.\mathrm{p}_{2-3}<0,05\right)$.

Застосування карбацетаму протягом 7 діб тваринам з гострою крововтратою, ускладненою ішемією-реперфузією кінцівки, порівняно з тваринами без корекції (рис. 2) зумовлювало істотне збільшення величини АПІ - на 50,4 \% $(p<0,05)$. 3а умов уведення карбацетаму протягом 14 діб показник зростав на $54,6 \%(p<0,05)$, проте не досягав рівня контролю й залишався на 64,9 \% меншим $(p<0,05)$.

Отримані результати свідчать про те, що внаслідок ішемії-реперфузії кінцівки в печінці зростає величина АПІ з максимумом через 7 діб спостереження. Слід зазначити, що наведені відхилення величини АПІ зумовлені як зростанням вмісту ТБК-активних продуктів ПОЛ, так і значно більшим підвищенням активності каталази. Подібні порушення, на думку окремих авторів, мають компенсаторний характер і виникають у відповідь на надходження у печінку прооксидантних 
Огляди літератури, оригінальні дослідження, погляд на проблему, випадок з практики, короткі повідомлення

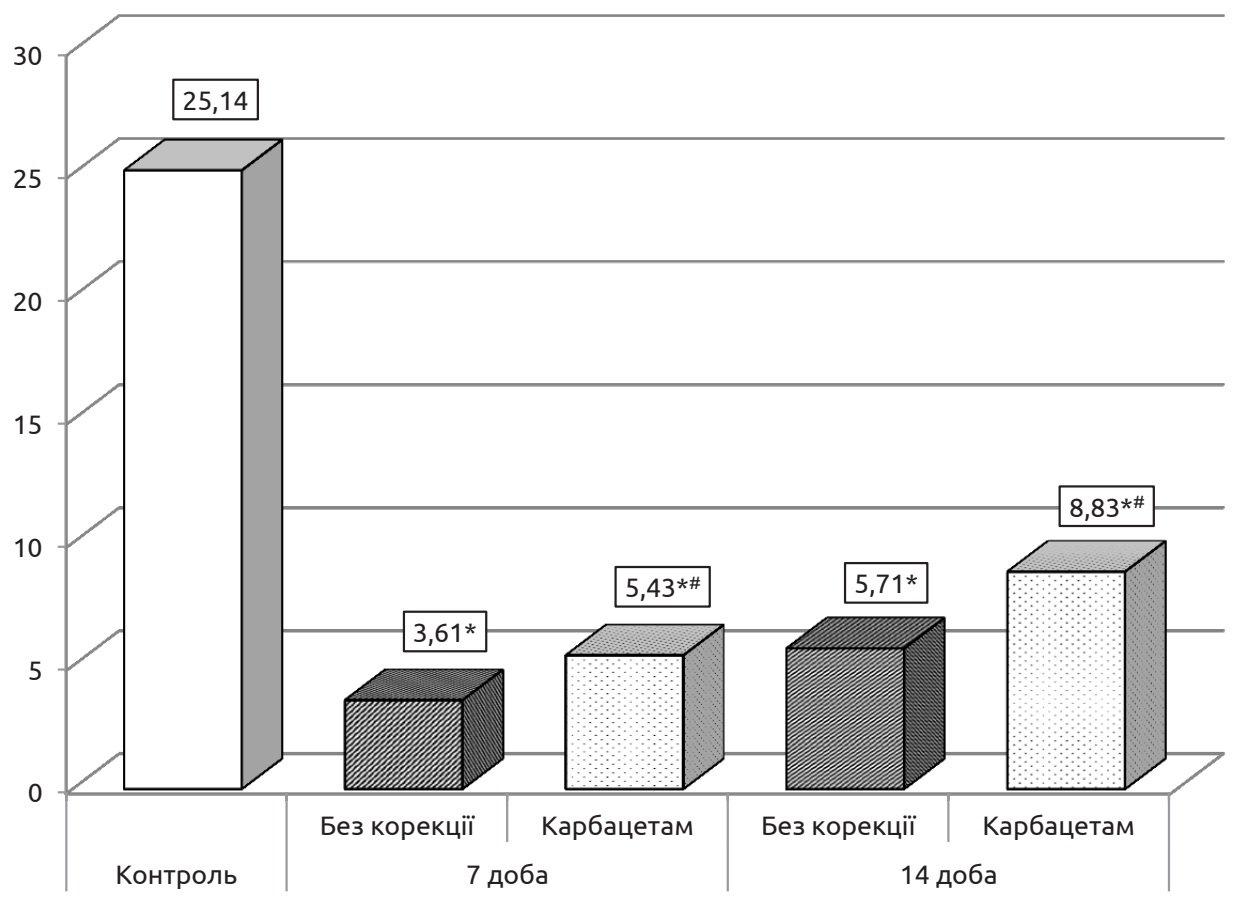

Рис. 2. Вплив карбацетаму на величину АПІ печінки (ум. од.) після гострої крововтрати, ускладненої ішемієюреперфузією кінцівки.

Примітка. * - відмінності стосовно контролю статистично вірогідні, p<0,05; \# - відмінності стосовно групи без корекції статистично вірогідні, $\mathrm{p}<0,05$.

чинників та ендотоксинів з ішемізованої протягом двох годин кінцівки після її реперфузії $[1,5]$. Варто зауважити, що виявлені порушення $\epsilon$ тривалими в часі й не стихають до закінчення експерименту (14 доба), що, очевидно, $\epsilon$ свідченням напруження антиоксидантних механізмів на тлі тривалого в часі автокаталітичного збільшення активності процесів пОЛ.

Під впливом гострої крововтрати величина АПІ у печінці різко зменшується, що викликано зростанням вмісту ТБК-активних продуктів ПОЛ та зниженням активності каталази і вказує на посилення прооксидантних механізмів і виснаження чинників антиоксидантного захисту. В основі цих процесів лежить посилення гіпоксії органа внаслідок обмеженого кровопостачання. Проте ми вперше встановили, що додаткова двогодинна ішемія кінцівки з наступною реперфузією на тлі гострої крововтрати зумовлює ще більше зниження величини АПІ в печінці, що виявилося статистично вірогідним, порівняно з іншими дослідними групами. Отже сукупність прооксидантних чинників та токсинів з ішемізованої протягом двох годин кінцівки, який умовно вважається безпечним терміном, за умов гострої крововтрати чинять додатковий негативний вплив на паренхіму печінки, що зумовлює посилення процесів ліпопероксидації та виснаження антиоксидантного захисту і $\epsilon$ одним з пускових механізмів системної відповіді організму на запалення [2]. Подібну реакцію з боку печінки на ішемію-реперфузію кінцівки за умов поєднаної травми живота встановлено й іншими авторами [14].

3 метою корекції виявлених порушень ми застосували карбацетам, який за умов гострої крововтрати, ускладненої ішемією-реперфузією кінцівки, посилював прооксидантний вплив на паренхіму нирок [9]. Дослідження показали, що препарат зумовлював суттєве зростання величини АПІ в печінці після 7-14 діб застосування. В основі його позитивної дії, очевидно, лежить антиоксидантна, імуномодулювальна, детоксикаційна, мембраностабілізувальна і тканинопротекторна дія, що було доведено окремими авторами [4]. Таким чином, карбацетам $\epsilon$ перспективним засобом корекції прооксидантних порушень у печінці за умов гострої крововтрати, ускладненої ішемією-реперфузією кінцівки, що вимагає подальшого доклінічного вивчення.

Висновки. 1. Унаслідок двогодинної ішемії та реперфузії кінцівки в печінці суттєво зростає величина АПІ з максимумом через 7 діб реперфузійного періоду, яка до 14 доби не досягає рівня контрольної групи, що свідчить про значну активацію в печінці прооксидантних чинників та компенсаторне посилення антиоксидантного захисту.

2. За умов гострої крововтрати величина АПІ в печінці різко зменшується, досягає мінімуму че- 
Огляди літератури, оригінальні дослідження, погляд на проблему, випадок з практики, короткі повідомлення рез 1 добу й до 14 доби не досягає рівня контролю, що свідчить про значне посилення прооксидантних механізмів, викликане гіпоксією органа. Додаткове моделювання ішемії-реперфузії кінцівки на тлі гострої крововтрати супроводжується найбільшим зниженням величини АПІ в печінці у всі терміни спостереження, що вказує на нашарування патогенних механізмів обох втручань.

3. Застосування впродовж 7-14 діб реперфузійного періоду карбацетаму у тварин з гострою

крововтратою, ускладненою ішемією-реперфузією кінцівки, порівняно з тваринами без корекції, викликає істотне зростання величини АПІ, що свідчить про ефективність препарату за умов модельованої патології.

Перспективи подальших досліджень. У перспективні доцільно поглибити дослідження функціональних порушень печінки за умов гострої крововтрати та ішемії-реперфузії кінцівки та встановити за цих умов ключові механізми дії карбацетаму.

\section{ЛІТЕРАТУРА}

1. Біохімічні зміни у сироватці крові щурів при ішемічно-реперфузійному синдромі (експериментальне дослідження) / А. А. Телев'як, Т. О. Вересюк, П. Р. Сельський, І. І. Боймиструк // Здобутки клінічної і експериментальної медицини. - 2018. - № 2 (34). - С. 122-128.

2. Гудима А. А. Антиоксидантно-прооксидантний та цитокіновий баланс у пізній період комбінованої травми В експерименті / А. А. Гудима, Т. В. Кащак, К. В. Шепітько // Світ медицини та біології. - 2019. - № 1 (67). C. $42-47$.

3. Доклінічні дослідження лікарських засобів: метод. рекомендації / за ред. О. В. Стефанова. - К. : Авіценна, 2001. -528 с.

4. Козак Д. В. Вплив карбацетаму на антиоксидантний-прооксидантний баланс тканини серця, легень і печінки в динаміці політравми / Д. В. Козак // Шпитальна хірургія. - 2014. - № 1 (65). - С. 40-42.

5. Максимів Р. В. Динаміка балансу антиоксидантно-прооксидантних механізмів у внутрішніх органах під впливом артеріального джгута і реперфузії кінцівки / Р. В. Максимів, А. А. Гудима, В. М. Сидоренко // Шпитальна хірургія. Журнал імені Л. Я. Ковальчука. - 2017. № 1. - С. 37-44.

6. Метод определения активности каталазы / М. А. Королюк, Л. И. Иванова, И. Г. Майорова, В. Е. Токарев // Лабораторное дело. - 1988. - № 1. - С. 16-19.

7. Телевяк А. Т. Динаміка показників перекисного окислення ліпідів та антиоксидантного захисту в м'язовій тканині задніх кінцівок щурів при розвитку ішемічнореперфузійного синдрому (експериментальне дослідження) / А. Т. Телевяк // Здобутки клінічної і експериментальної медицини. - 2018. - № 3 (35). - С. 132-139.

8. Цимбалюк Г. Ю. Стан добового діурезу нирок в умовах ішемічно-реперфузійного синдрому кінцівок, травми органів черевної порожнини, ускладненої гіповолемічним шоком, та їх поєднання у ранньому періоді травматичної хвороби / Г. Ю. Цимбалюк // Здобутки клінічної і експериментальної медицини. -2018. - № 3 (35).C. $163-169$.

9. Шацький В. В. Динаміка антиоксидантно-прооксидантного балансу кіркового і мозкового шарів нирки після гострої крововтрати, ускладненої ішемієюреперфузією кінцівки, та його корекція карбацетамом / В. В. Шацький, А. А. Гудима, Л. Я. Федонюк // Здобутки клінічної і експериментальної медицини. - 2019. № 4. - С. 144-153.

10. An evidence-based prehospital guideline for external hemorrhage control: American College of Surgeons Committee on Trauma /E. M. Bulger, D. Snyder, K. Schoelles [et al.] // Prehosp. Emerg. Care. - 2014. - No. 18. P. 163-173.

11. Clasper J. C. Limb complications following prehospital tourniquet use / J. C. Clasper, K. V. Brown, P. Hill // J. R. Army Med. Corps. - 2009. - Vol. 155. - P. 200-202.

12. Comparison of changes in markers of muscle damage induced by eccentric exercise and ischemia/reperfusion / Q. S. Su, J. G. Zhang, R. Dong [et al.] // Scand. J. Med. Sci. Sports. - 2010. - Vol. 20, No. 5. - P. 748-756.

13. Concentration decrease of nitric oxide in the postischemic muscle is not only caused by the generation of O2- / F. Stoffels, F. Lohöfener, M. Beisenhirtz [et al.] // Microsurgery. - 2007. - Vol. 27, No. 6. - P. 565-568.

14. Kuzminskyi I. V. Bile production features in case of ischemic-reperfusion syndrome of limbs, abdominal trauma complicated with massive blood loss / I. V. Kuzminskyi, V. O. Krylyuk, M. A. Maksymenko // Journal of Education, Health and Sport, formerly Journal of Health Sciences. 2018. - Vol. 8, No. 10. - P. 209-218.

15. Leukocytes and the inflammatory response in ischemiareperfusion injury / I. Francischetti, J. B. Moreno, M. Scholz, W. B. Yoshida // Rev. Bras. Cir. Cardiovasc. 2010. - Vol. 25 (4). - P. 575-584.

16. Morsey $\mathrm{H}$. Patients with critical ischemia of the lower limb are at risk of developing kidney dysfunction / H. Morsey, M. Aslam, N. Standfield // Am. J. Surg. - 2003. Vol. 185. - P. 360-363.

17. Murphy E. Mechanisms underlying acute protection from cardiac ischemia-reperfusion injury / E. Murphy, C. Steenbergen // Physiol. Rev. - 2008. - Vol. 88 (2). P. 581-609.

18. Snyder D. Efficacy of prehospital application of tourniquets and hemostatic dressings to control traumatic external hemorrhage / D. Snyder, A. Tsou, K. Schoelles. Washington DC, United States, 2014. - 147 p. - URL : https://www.ems.gov/pdf/research/Studies-and-Reports/ Prehospital_Applications_Of_Tourniquest_And_Hemostatic_Dressings.pdf

19. Tsimbalyuk G. Y. Features of transport of potassium ions in ischemia-reperfusion syndrome of lower extremities, abdominal trauma and hypovolemic shock / G. Y. Tsimbalyuk, V. O. Krylyuk // Journal of Education, Health and Sport. - 2018. - Vol. 8, No. 9. - P. 1785-1795. 
Огляди літератури, оригінальні дослідження, погляд на

20. Van der Spuy L. Complications of the arterial tourniquet / L. Van der Spuy // South Afr. J. Anaesth. Analg. 2012. - Vol. 18 (1). - P. 14-18.

21. Volotovska N. V. Changes in the glutathione system's activity of internal organs in the first hours of experi- лему, випадок з практики, короткі повідомлення mental limb ischemia-reperfusion syndrome, combined with blood loss and mechanical injury / N. V. Volotovska, T. C. Nhokwara, I. V. Zhulkevych // Здобутки клінічної і експериментальної медицини. - 2019. - No. 1. - С. 23-27. URL : https://doi.org/10.11603/1811-2471.2019.v0.i1.10043.

\section{REFERENCES}

1. Televiak, A.T., Veresiuk, T.O., Selskyy, P.R., \& Boymystruk, I.I. (2018). Biokhimichni zminy u syrovatsi krovi shchuriv pry ishemichno-reperfuziinomu syndromi (eksperymentalne doslidzennia) [Biochemical changes in blood serum of rats with reperfusion-ischemic syndrome (the experimental study)]. Zdobutky klinichnoi $i$ eksperymentalnoi medytsyny - Achievements of Clinical and Experimental Medicine, 2 (34), 122-128 [in Ukrainian].

2. Hudyma, A.A., Kashchak, T.V., \& Shepitko, K.V. (2019). Antyoksydantno-prooksydantnyi ta tsytokinovyi balans u piznii period kombinovanoi travmy v eksperymenti [Antioxidant-prooxidant and cytokine balance in the late period of combined trauma in the experiment]. Svit medytsyny ta biolohii- World of Medicine and Biology, 1 (67), 4247 [in Ukrainian].

3. Stefanov, O.V. (Ed). (2001). Doklinichni doslidzhennia likarskykh zasobiv: metod. rek. [Preclinical drug research: guidelines]. Kyiv: Avitsenna [in Ukrainian].

4. Kozak, D.V. (2014). Vplyv karbatsetamu na antyoksydantnyi-prooksydantnyi balans tkanyny sertsia, lehen i pechinky $v$ dynamitsi politravmy [Influence of carbacetam on antioxidant-prooxidant balance of heart, lung and liver tissue in the dynamics of polytrauma]. Shpytalna khirurhiia - Hospital Surgery, 1 (65), 40-42 [in Ukrainian].

5. Maksymyv, R.V., Hudyma, A.A., \& Sydorenko, V.M. (2017). Dynamika balansu antyoksydantno-prooksydantnykh mekhanizmiv u vnutrishnikh orhanakh pid vplyvom arterialnoho dzhhuta i reperfuziii kintsivky [Dynamic of balance of antioxidant-prooxidant mechanism in internal organs under the influence of blood harnesses and limb reperfusion]. Shpytalna khirurhiia. Zhurnal imeni L.Ya. Kovalchuka - Hospital Surgery. Journal named by L. Ya. Kovalchuk, 1, 37-44 [in Ukrainian].

6. Korolyuk, M.A., Ivanova, L.I., Mayorova, I.H., \& Tokarev, V.Ye. (1988). Metod opredeleniya aktivnosti katalazy [Method for determination of catalase activity]. Laboratornoye delo-Laboratory Work, 1, 16-19 [in Russian].

7. Televiak, A.T. (2018). Dynamika pokaznykiv perekysnoho okyslennia lipidiv ta antyoksydantnoho zakhystu v miazovii tkanyni zadnikh kintsivok shchuriv pry rozvytku ishemichno-reperfuziinoho syndromu (eksperymentalne doslidzhennia) [The dynamic of indicators of lipid peroxidation and antioxidant protection in muscle tissue of the hind limbs of the rats in development of the ischemicreperfusion syndrome (experimental study)]. Zdobutky klinichnoi i eksperymentalnoi medytsyny - Achievements of Clinical and Experimental Medicine, 3 (35), 132-139 [in Ukrainian].

8. Tsymbalyuk, H.Yu. (2018). Stan dobovoho diurezu nyrok $v$ umovakh ishemichno-reperfuziinoho syndromu kintsivok, travmy orhaniv cherevnoi porozhnyny, uskladnenoi hipovolemichnym shokom, ta yikh poiednannia u rannomu periodi travmatychnoi khvoroby [Daily urine re- nal state under ischemic-reperfusion syndrome of limbs, abdominal injury with hypovolemic shock and their combination in the early period of traumatic disease]. Zdobutky klinichnoi i eksperymentalnoi medytsyny - Achievements of Clinical and Experimental Medicine, 3 (35), 163-169 [in Ukrainian].

9. Shatsky, V.V., Gudyma, A.A., \& Fedoniuk, L.Ya. (2019). Dynamika antyoksydantno-prooksydantnoho balansu kirkovoho i mozkovoho shariv nyrky pislia hostroi krovovtraty, uskladnenoi ishemiieiu-reperfuziieiu kintsivky, ta yoho korektsiia karbatsetamom [Dynamics of antioxidantprooxidant balance of renal cortex and medulla after acute blood loss complicated by ischemia-reperfusion of the extremity, and its correction with carbacetam]. Zdobutky klinichnoi i eksperymentalnoi medytsyny - Achievements of Clinical and Experimental Medicine, 4, 144-153 [in Ukrainian].

10. Bulger, E.M., Snyder, D., Schoelles, K., Gotschall, C., Dawson, D., Lang, E., ..., \& McSwain Jr, N. (2014). An evidence-based prehospital guideline for external hemorrhage control: American College of Surgeons Committee on Trauma. Prehosp. Emerg. Care, 18, 163-173.

11. Clasper, J.C., Brown, K.V., \& Hill, P. (2009). Limb complications following pre-hospital tourniquet use. J. $R$. Army Med. Corps., 155, 200-202.

12. Su, Q.-S., Zhang, J.-G., Dong, R., Hua, B., \& Sun, J.Z. (2010). Comparison of changes in markers of muscle damage induced by eccentric exercise and ischemia/reperfusion. Scand. J. Med. Sci. Sports, 20, 5, 748-756.

13. Stoffels, F., Lohöfener, F., Beisenhirtz, M., Lisdat, F., \& Büttemeyer, R. (2007). Concentration decrease of nitric oxide in the postischemic muscle is not only caused by the generation of O2: Microsurgery, 27, 6, 565-568.

14. Kuzminskyi, I.V., Krylyuk, V.O., \& Maksymenko, M.A. (2018). Bile production features in case of ischemic-reperfusion syndrome of limbs, abdominal trauma complicated with massive blood loss. Journal of Education, Health and Sport, formerly Journal of Health Sciences, 8, 10, 209-218.

15. Francischetti, I., Moreno, J.B., Scholz, M., \& Yoshida, W. B. (2010). Leukocytes and the inflammatory response in ischemiareperfusion injury. Rev. Bras. Cir. Cardiovasc., 25 (4), 575-584.

16. Morsey, H., Aslam, M., \& Standfield, N. (2003). Patients with critical ischemia of the lower limb are at risk of developing kidney dysfunction. Am. J. Surg., 185, 360-363.

17. Murphy, E., \& Steenbergen, C. (2008). Mechanisms underlying acute protection from cardiac ischemia-reperfusion injury. Physiol. Rev., 88 (2), 581-609.

18. Snyder, D., Tsou, A., \& Schoelles, K. (2014). Efficacy of prehospital application of tourniquets and hemostatic dressings to control traumatic external hemorrhage. Washington DC, United States. 147 p. Retrieved from: https://www.ems.gov/pdf/research/Studies-and-Reports/ 
Огляди літератури, оригінальні дослідження, погляд на проблему, випадок з практики, короткі повідомлення Prehospital_Applications_Of_Tourniquest_And_Hemostatic_Dressings.pdf

19. Tsimbalyuk, G.Y., \& Krylyuk, V.O. (2018). Features of transport of potassium ions in ischemia-reperfusion syndrome of lower extremities, abdominal trauma and hypovolemic shock. Journal of Education, Health and Sport, 8, 9, 1785-1795.

20. Van der Spuy, L. (2012). Complications of the arterial tourniquet. South Afr. J. Anaesth Analg., 18 (1), 14-18.

21. Volotovska, N.V., Nhokwara, T.C., \& Zhulkevych, I.V. (2019). Changes in the glutathione systems activity of internal organs in the first hours of experimental limb ischemia-reperfusion syndrome, combined with blood loss and mechanical injury. Zdobutky klinichnoi i eksperymentalnoi medytsyny - Achievements of Clinical and Experimental Medicine, (1), 23-27. Retrieved from: https://doi. org/10.11603/1811-2471.2019.v0.i1.10043

\section{ВЛИЯНИЕ ОСТРОЙ КРОВОПОТЕРИ, ОСЛОЖНЕННОЙ ИШЕМИЕЙ-РЕПЕРФУЗИЕЙ КОНЕЧНОСТИ, НА АНТИОКСИДАНТНО-ПРООКСИДАНТНЫЙ БАЛАНС ПЕЧЕНИ И ЕГО КОРРЕКЦИЯ КАРБАЦЕТАМОМ}

ФИ. И. Горбань

Тернопольский национальный медицинский университет имени И. Я. Горбачевского МОз Украины

РЕЗЮМЕ. Цель - Выяснить Влияние острой кровопотери, осложненной ишемией-реперфузией конечности, на антиоксидантно-прооксидантный баланс печени и эффективность коррекции выявленных нарушений карбацетамом.

Материал и методы. Эксперименты выполнены на 108 нелинейных крысах-самцах массой 200-220 г. Всех животных разделили на пять групп: контрольную и четыре опытных. Все вмешательства выполнены под тиопенталонатриевым наркозом. В первой опытной группе животным моделировали ишемию-реперфузию конечности путем наложения проксимально на левую лапку полоски эластичного жгута «SWAT-T» (CШA) шириной 10 мм на 120 мин. Во второй опытной группе моделировали острую кровопотерю (20 \% от объема циркулирующей крови) путем пересечения бедренной вены. В третьей опытной группе эти повреждения сочетали. В четвертой опытной группе животным с острой кровопотерей и ишемией-реперфузией конечности внутрибрюшинно вводили карбацетам в дозе 5 мг на килограмм массы животного. В контрольной группе животных вводили в наркоз, применяя эквивалентную дозу тиопентала натрия, накладывали жгут на 2 часа без прекращения кровотока и в дальнейшем брали для исследований через 1 ч.

Через 1 и 2 часа, а также через 1, 7 и 14 суток в условиях тиопенталонатриевого наркоза животных опытных групп выводили из эксперимента методом тотального кровопускания из сердца. В гомогенате печени определяли содержание реагентов к тиобарбитуровой кислоте и активность каталазы. На основании этих данных рассчитывали антиоксидантно-прооксидантный индекс (АПИ).

Результаты. Вследствие моделирования только ишемии-реперфузии конечности в печени возрастала величина АПИ с максимумом через 7 суток наблюдения, что обусловлено как повышением содержания реагентов к тиобарбитуровой кислоте, так и увеличением активности каталазы. До 14 суток величина АПИ снижалась, однако не достигала уровня контроля. Под влиянием острой кровопотери величина АПИ в печени резко уменьшалась, что вызвано ростом содержания реагентов к тиорбарбитуровой кислоте на фоне снижения активности каталазы. Дополнительная двухчасовая ишемия конечности с последующей реперфузией на фоне острой кровопотери предопределяла еще большее снижение величины АПИ в печени, что оказалось статистически достоверным по сравнению с другими опытными группами во все сроки наблюдения. Применение карбацетама в группе животных с острой кровопотерей, осложненной ишемией-реперфузией конечности, по сравнению с животными без коррекции, вызвало существенный рост величины АПИ через 7-14 суток эксперимента, что свидетельствовало о его антиоксидантном влиянии.

Выводы. Вследствие двухчасовой ишемии и реперфузии конечности в печени существенно возрастает величина АПИ с максимумом через 7 суток реперфузионного периода, которая до 14 суток достигает уровня контрольной группы. В условиях острой кровопотери величина АПИ в печени резко уменьшается, достигает минимума через 1 сутки и до 14 суток остается существенно меньше, чем в контроле. Дополнительное моделирование ишемии-реперфузии конечности на фоне острой кровопотери сопровождается наибольшим снижением величины АПИ в печени во все сроки наблюдения.

Применение в течение 7-14 суток реперфузионного периода карбацетама у животных с острой кровопотерей, осложненной ишемией-реперфузией конечности, по сравнению с животными без коррекции, вызывает существенный рост величины АПИ, что свидетельствует об эффективности препарата в условиях моделируемой патологии.

КЛЮЧЕВЫЕ СЛОВА: печень; кровопотеря; ишемия-реперфузия конечности; антиоксидантно-проксидантний баланс; карбацетам. 


\section{THE EFFECT OF ACUTE BLOOD LOSS COMPLICATED BY LIMB ISCHEMIA-REPERFUSION ON THE ANTIOXIDANT-PROOXIDANT BALANCE OF THE LIVER AND ITS CORRECTION BY CARBACETAM}

OI. I. Horban

\section{Horbachevsky Ternopil National Medical University}

SUMMARY. The aim - to establish the effect of acute blood loss complicated by limb ischemia-reperfusion on the antioxidant-prooxidant balance of the liver and the efficacy of the carbacetam in correction of identified abnormalities.

Material and Methods. The experiments were conducted on 106 non-linear male rats weighing 200-220 g. All animals were divided into five groups: control and four experimental ones. All procedures were carried out under thiopental sodium anesthesia. In the first experimental group, animals were induced the limb ischemia-reperfusion injury by a method of applying a band of an elastic tourniquet SWAT-T. (USA), the width of 10 mm, proximally to the rat's left hind leg for 120 minutes. The animals of the second experimental group were inflicted the acute blood loss ( $20 \%$ of circulating blood volume) by severing a femoral vein. In the third experimental group, these lesions were combined. In the fourth experimental group, animals with acute blood loss concurrently with limb ischemia-reperfusion were intraperitoneally injected with carbacetam at a dose of $5 \mathrm{mg} / \mathrm{kg}$ body weight. Animals were administered anesthesia receiving an equivalent dose of thiopental sodium, as well as were applied a tourniquet for 2 hours without stopping the bleeding and were subsequently used for research an hour later.

After 1 and 2 hours as well as 1, 7 and 14 days, the animals were withdrawn from the experiment by means of complete exsanguination from the heart under thiopental sodium anesthesia. Thiobarbituric acid reactive substances content and catalase activity were determined in the liver homogenate. The prooxidant/antioxidant ratio (ProAntidex) was calculated based on the above data.

Results and Discussion. The prooxidant/antioxidant ratio value increased in the liver with a maximum of abnormalities after 7 days of the observation as a result of the limb ischemia-reperfusion model only, which was caused by an increase in both the thiobarbituric acid reactive substances content and catalase activity. The value of ProAntidex decreased up to $14^{\text {th }}$ day not reaching the control level. The prooxidant/antioxidant ratio value severely decreased in the liver under the effect of acute blood loss, which was attributable to an increase in the thiobarbituric acid reactive substances content simultaneously with a decrease in catalase activity. An additional two-hour limb ischemia followed by further reperfusion concurrently with the acute blood loss caused an even greater decrease in the value of ProAntidex in the liver, which was statistically significant at all observation periods compared to the other experimental groups. Administration of the carbacetam to the animals with acute blood loss complicated by limb ischemia-reperfusion, compared to the animals without correction, resulted in substantial increase in prooxidant/antioxidant ratio value after 7 and 14 days of the experiment, indicating its prooxidant effect.

Conclusions. The prooxidant/antioxidant ratio value considerably increases in the liver as a result of two-hour limb ischemia and reperfusion injury, with a maximum of abnormalities after 7 days of reperfusion period, not reaching the control level up to 14th day. In the presence of acute blood loss the value of ProAntidex in the liver severely decreases, reaches the minimum after 1 day and remains substantially lower up to $14^{\text {th }}$ day than in the control group. An additional limb ischemia-reperfusion injury model simultaneously with acute blood loss is accompanied by the most significant decrease in the prooxidant/antioxidant ratio value in the liver at all observation periods.

Administration of the carbacetam to the animals with acute blood loss complicated by limb ischemia-reperfusion within 7-14 days of the reperfusion period, compared to the animals without treatment, leads to considerable increase in the prooxidant/antioxidant ratio value, indicating the efficacy of the medication in the modelled pathology.

KEY WORDS: liver; blood loss; limb ischemia-reperfusion; antioxidant-prooxidant balance. 